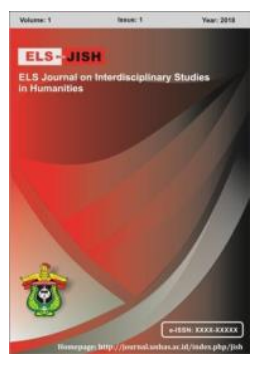

ELS-JISH

ELS Journal on Interdisciplinary Studies on Humanities

Volume 3 Issue 3, 2020

ISSN (print) : 2621-0843

ISSN (online) : 2621-0835

Homepage : http://journal.unhas.ac.id/index.php/jish

\title{
Adult EFL Learning in Digital Era
}

\author{
Umar $^{1}$, Noer Jihad Saleh ${ }^{2}$, Abdul Hakim Yassi ${ }^{3}$, Nasmilah $^{4}$ \\ ${ }^{1}$ umarsahaf@yahoo.com
}

\begin{abstract}
This research aims at finding out the use of Digital Language Learning better than the Traditional Language Learning to enrich the Adult EFL learners' schema in developing their speaking ability. This research also aimed at scrutinizing how the finding of Digital Learning Learning (DLL) challenges the theory of schema for adult EFL learners and exploring the learner's attitude. This research used a quasi-experimental research design. The samples of this research were the third-semester students of Universitas Sulawesi Barat which belonged to two groups; the experimental group and the control group. The research data were collected using two kinds of instruments; the speaking test and the questionnaire given to both groups. The research results indicated that: (1) the Digital Language Learning can significantly improve the learners' schema in developing the speaking ability than Traditional Language Learning. (2) This research disclosed some Digital Language Learning features namely knowledge sharing, active and collaborative learning, learner-centered, activity, and networking. Those features are the digital language learning better than Traditional Language Learning to enrich adult EFL learners in developing their speaking ability. (3) Most of them agreed that the Digital Language Learning better than the Traditional Language Learning enriches the learners' schema in developing speaking ability. Of most significant importance, this research's novelty contributes to the schema theory that digital language learning better than traditional language learning, particularly interactivity and networking.
\end{abstract}

Keywords: Speaking Ability, Digital Language Learning, Traditional Language Learning, Schema Theory

How to cite: Umar, Saleh, N. J., Yassi, H. A., \& Namilah (2020). Adult EFL Learning in Digital Era. ELS Journal on Interdisciplinary Studies in Humanities, 3(3), 344-351. DOI:

https://doi.org/10.34050/elsjish.v3i3.8005

\section{Introduction}

Technology advancement can inevitably impact a nation's cultural and social aspects (Rahman, 2017). It is greatly indicated by strict competition and several mastery of technology (Ermawati, 2018). Technology in the digital era is very important as a modern communication tool to challenge the traditional communication tool in our society like culture, politics, economy, including education. It has also the important role of the recent foreign language learning. Susiati (2019) Stated that effectiveness in the teaching and learning process will be generated if the teacher can use the instructional methods appropriate to the students 'circumstances and the content to be addressed.

1,2,3,4,Hasanuddin University, Indonesia. 
Digital classroom learning becomes part of the majority of classrooms. It is integrated and emphasized since it precedes formal and informs. Digital learning is a rational answer to previous pedagogical patterns' growth using a range of teaching tools, often assisted by new technologies. In short, different teaching techniques, the physical presence of both teachers and students, elements of regulation such as time and speed, and at least some instruction mediated through technical channels for content delivery are the key criteria for digital learning.

This research's main concern is that information of the adult English Learners get digital classroom learning and traditional classroom learning in teaching speaking skills as identified in West Sulawesi, Universitas Sulawesi Barat (UNSULBAR). They are becoming increasingly difficult to ignore the social context of new digital technology and new learning paradigm. Digital learning provides enormous opportunities for teaching and learning, especially in developing speaking ability, yet it is still underdeveloped. What is more, it is no longer possible for teachers to ignore such a technology advance, while they are expected to provide learners with opportunities to take control of their learning. However, English teachers are challenged to plan the classroom, including developing and preserving maximum learning environments with digital technology (Aswad et al. 2019). In the beginning, the survey confirmed that almost all learners have high access to computers and other technology devices. The result of this survey reported that adult learners own portable devices, particularly notebook computers, portable media players, and mobile phones. High access to these tools indicated high mobility and quick access to internet facilities. Based on the results with other studies, it is convincing clear that UNSULBAR learners, especially majoring in English Education Study Program, are already exposed to various types of digital technology. They are comfortable level with the use of digital tools in learning English to develop their speaking ability.

On the contrary, before the digital technology comes into existence, teaching and learning activities in UNSULBAR are still largely directed by face to face or traditional classroom learning methods. Digital technologies are predominantly used for entertainment. Due to digital development, UNSULBAR adult learners, in response to the need for academics to develop speaking ability by adopting digital technologies to transform the traditional learning method. More specifically, this research how the digital classroom learning challenges the schema theory in transforming pedagogies in the digital era.

This research aimed at providing descriptive accounts of Digital Language Learning (DLA) in the development of speaking ability for adult EFL learners and, hopefully, how presents recommendations on the future Digital Language Learning (DLL) that can contribute to the development of language learning and challenge the schema theory. More specifically, this research aims at providing some objectives: to find out whether or not the use of Digital Language Learning better than the Traditional Language Learning to enrich the adult EFL learners' Schemata in developing of their speaking ability, to scrutinize how the finding of Digital Learning Learning (DLL) challenges the theory of schema for adult EFL 
learners, and to explore the learners' attitude toward the Digital Language Learning (DLL) in development of speaking ability for adult EFL Learners

\section{Method}

This research used a quasi-experimental research design. The samples of this research were the third-semester students of Universitas Sulawesi Barat, which belonged to two groups; the experimental and control groups. The research data were collected using two kinds of instruments; the speaking test and the questionnaire which were given to the both groups.

\subsection{Technique of Data Analysis}

Data Analysis was the collecting and organizing of the data that allowed to answer the research questions. As mentioned earlier, there were two instruments used to collect the data; questionnaire and test.

Moreover, questionnaires and tests were techniques used to collect quantitative data. The researcher used t-test in SPSS to examine the result of test. It was to find out the correlation among learners' schema, digital language learning and the development of learners' speaking ability

In one hand, the question items in the questionnaire were converted to Likert Scale. It consists of five point scale that relates with the learners' opinion. The data are, further, converted into the interval of mean values on a scale of 1 up to 5 using a range of the factual score. It, then, will be analyzed through SPSS version 16.0. Descriptive statistics is used to describe the result items in the questionnaire. The following is an example of Likert Scale.

Table 1. Likert Scale and Meaning Best (1981:182)

\begin{tabular}{clc}
\hline Score & \multicolumn{1}{c}{ Category } & Mean range \\
\hline 1 & Strongly disagree & 1 \\
\hline 2 & Disagree & 2 \\
\hline 3 & Undecided & 3 \\
\hline 4 & Agree & 4 \\
\hline 5 & Strongly agree & 5 \\
\hline
\end{tabular}

The Classifying the score of students into five levels as follows:

a. Scoring the student's answer in the tests by using the following formula:

Maximum score $=25$

Score $=\frac{\text { the result of score }}{\text { Maximum score }} \times 100 \%$

Table 2. Classification of Students' Answer

\begin{tabular}{ll}
\hline & Classification \\
\hline $96-100$ & Excellent \\
\hline $86-95$ & Very good \\
\hline $76-85$ & Good \\
\hline $66-75$ & Fairly good \\
\hline $55-65$ & Fairly \\
\hline $36-55$ & Poor \\
\hline $00-35$ & Very Poor \\
\hline
\end{tabular}


b. Tabulating the scores of the student's test result.

\section{Findings}

\subsection{Score Classification of Students' Pretest of Speaking Ability}

In the table below, the researcher presents the percentage of students' pretest score for experimental group and control group.

Table 3. The Percentage of Students' Pretest Score of Speaking Ability

\begin{tabular}{cccccc}
\hline Classification & \multicolumn{3}{c}{ Experimental Group } & \multicolumn{2}{c}{ Control Group } \\
\cline { 2 - 6 } & Score & $\mathrm{F}$ & $\%$ & $\mathrm{~F}$ & $\%$ \\
\hline Excellent & $96-100$ & 0 & 0 & 0 & 0 \\
very Good & $86-95$ & 0 & 0 & 0 & 0 \\
good & $76-85$ & 4 & 16 & 4 & 16 \\
Fairly good & $66-75$ & 11 & 44 & 7 & 28 \\
fairly & $56-65$ & 3 & 12 & 7 & 28 \\
Poor & $36-55$ & 5 & 20 & 7 & 28 \\
Very poor & $0-35$ & 2 & 8 & 0 & 0 \\
\hline Total & & 25 & 100 & 25 & 100 \\
\hline
\end{tabular}

On the basis of the above table, it was understood that most of the experimental group's pretest scores for students were in a reasonably good range. 11 students were reasonably good or 44 percent, 4 students were graded as good or 16 percent, 3 students were reasonable or 12 percent, 5 students were poor or 20 percent, and 2 students were really poor or 8 percent. There was no student who got excellent and very good.

In the control group, the data showed that of the twenty-five students, 4 students were in a good class or 16 percent, 7 students were fairly good or 28 percent, 7 students were graded as fair or 28 percent, 7 students were poor or 28 percent, and no one student was very poor, very good and excellent.

\subsection{Score Classification of Students' Posttest of Speaking Ability}

The table showed below that the percentage of students' post-test scores in speaking ability taught using Digital Language Learning differed from those who taught naturally by using Traditional Language Learning.

Table 4. The Percentage of Students' Posttest Score of Speaking Ability

\begin{tabular}{cccccc}
\hline Classification & \multicolumn{3}{c}{ Experimental Group } & \multicolumn{2}{c}{ Control Group } \\
\cline { 2 - 6 } & Score & $\mathrm{F}$ & $\%$ & $\mathrm{~F}$ & $\%$ \\
\hline Excellent & $96-100$ & 0 & 0 & 0 & 0 \\
very Good & $86-95$ & 8 & 32 & 7 & 28 \\
good & $76-85$ & 13 & 52 & 9 & 36 \\
Fairly good & $66-75$ & 2 & 8 & 3 & 12 \\
fairly & $56-65$ & 2 & 8 & 6 & 24 \\
Poor & $36-55$ & 0 & 0 & 0 & 0 \\
Very poor & $0-35$ & 0 & 0 & 0 & 0 \\
\hline Total & & 25 & 100 & 25 & 100 \\
\hline
\end{tabular}


The above data showed that the performance of the students in the experimental group was improved, 8 students were very good or $32 \%, 13$ students were in good category or $52 \%, 2$ students were graded as fairly good and fair or $8 \%$ and no one student was poor, very poor and excellent.

No one student was excellent in the control group, 7 students were in a very good category or 28 percent, 9 students were good or 36 percent, 3 students were very good or 12 percent, 6 students were fair or 24 percent, and no one student was poor or very poor.

The data, on the other hand, showed that the achievements of the students in the experimental group were increased, it was the same as the control group. In comparison, 12 percent of students in the relatively good category and 24 percent of students in the fair category are also in the control group.

Table 5. Digital Language Learning Makes the Learners Easier to Enrich their Schemata than Traditional Language Learning

\begin{tabular}{ccccc}
\hline No & Answer & Frequency & Percentage & Score \\
\hline 1 & Strongly Agree & 5 & $10 \%$ & 25 \\
\hline 2 & Agree & 30 & $60 \%$ & 120 \\
\hline 3 & Undecided & 10 & $20 \%$ & 30 \\
\hline 4 & Disagree & 5 & $10 \%$ & 10 \\
\hline 5 & Strongly Disagree & 0 & 0 & 0 \\
\hline & Total & 50 & $100 \%$ & 175 \\
\hline
\end{tabular}

The total score was 175 , based on the table above. The highest score was decided upon. The ranking was 175 points: $250 \times 100$ points $=70$ percent. It demonstrated that $70 \%$ of digital language learning allows it easier for learners to enrich their schemes than conventional language learning.

\section{Discussion}

\subsection{The Achievement of Students' Speaking Ability}

As described in the previous section, the summary of data gathered through the test showed that the achievement of the students ' speaking skills was enhanced. It was endorsed by the rate mean score of the pretest and posttest outcome of the students. The previous explanation showed that the mean score of the students after speaking therapy was higher than before the treatment was offered.

It clearly demonstrated that the mean score of the students between the pretest and posttest results of both the experimental group and the control group. In this scenario, the mean pre-test score for the experimental group was 65.00 , which was classified as a fair category, and 64.80 for the control group, which was also classified as a fair category. After offering the medication, the mean scores were then increased. It indicated that both of them can be applied to improve the students' speaking skill achievement.

The investigator also found that the overall correct numbers of the students from either pretest or posttest were also enhanced. It could be shown that the mean scores between the pretest and posttest were increased where 
the mean posttest score for the experimental group was 85.00 that was graded as good category and 79.40 for the good category control group.

Both classes made gains in achieving the speaking skills of the students. Digital Language Learning taught the control group that Conventional Language Learning and the experimental group naturally taught.

The findings of the post-test in both the study group and the control group marked the enhancement of the speech skills of students. The enhancement rate of the experimental group, however, was greater than that of the control group. The facts can be seen by using SPSS version 16.0 (appendix) from the outcome of the t-test tests. The researcher found out that the probability was smaller than .05 or $.040<.05$ at the degree of freedom was 48 .

The investigator concluded that it strengthened both the study group and the control group. The experimental group, however, was substantially better in speaking than the control group.

\subsection{The Learners' Attitude to the Use of Digital Language Learning}

Earlier, this research explored the learners' attitude to the Digital Language Learning and Traditional Language Learning toward the learners' schema in developing the speaking ability.

As mentioned previously, this research also aimed to ilustrated the adult EFL learners' attitudes in Digital Language Learning toward the learners' schema in developing speaking ability.

This research's main concern is that information of the adult English Learners get digital classroom learning and traditional classroom learning in teaching speaking skil. They are becoming increasingly difficult to ignore the social context of new digital technology and new learning paraidgm. Digital learning provide enormous opportunities for teaching and learning espeacially to develop speaking ability, yet it is still underdeveloped. What is more, it is no longer possible for teachers to ignore such a technology edvance while they are expected to provide learners with opportunities to control their learning. However, the teachers are still reluctant with digital technology. In the begining, the survey comfirmed that almost all learners have high access to computers and others technology devices. This survey reported that the adult learners own portable devices particularly notebook computer, portable media players, and mobile phone (siti, 2019: 6-7). High access these tools indicated high mobolity an a a quick access to internet facilities. Based on the the results with other studies, it is convincinly clear that UNSULBAR learners, especially majoring in English Education Study Program are already exposed to various types of digital technology. They are comportable level with the use of digital tools in learning English to develop their speaking ability.

On contrary, before the digital technology comes into existence, teaching and learning activities are still being largely directed by face to face or traditional classroom learning method. Digital technologies are predominantly used for entertainment. Due to the digital development, adult learners, in response to the need for academics to develop speaking ability by adopting digital technologies to transform the traditional learning method. More specifically, this research 
finds out how the digital classroom learning challenges the schema theory in transforming pedagogies in the digital era.

Based on the most responses of the Adult EFLlearners to the all items of questionnaire, Most of them were agree (more than 80\%) and interested in joining with the Digital Language Learning than the Traditional Language Learning especially in the speaking class.

\section{Conclusion}

Both Digital Language Learning and Traditional Language Learning under this study toward learners' schema in developing speaking ability were improved. Both groups had progress to the students after treatment, but Digital Language Learning made more progress than Traditional Language Learning toward the learners' schema in developing speaking ability. The mean experimental group score was higher than the control group $(85.00>79.40)$, which was graded as very good and outstanding. In addition, the likelihood is less than .05 or $.040<.05$ based on the t-test analysis using the SPSS 16 asymptotic relevant (2-tailed) software. This implies that $\mathrm{H} 1$ was accepted, and the Ho statistical hypothesis was dismissed, of course. This suggests that the study group has been greatly improved compared to the control group. The researcher concluded that Digital Language Learning would greatly enhance learners' method in improving the ability to speak rather than conventional language learning.

This research disclosed some Digital Language Learning features namely knowledge sharing, active and collaborative learning, learner-centered, activity, and networking. Those features are the digital language learning better than Traditional Language Learning to enrich the adult EFL learners in developing their speaking ability. ased on the result of the questionnaire given to the respondents, most of them agreed that the Digital Language Learning better than the Traditional Language Learning to enrich the learners schema in developing speaking ability.

\section{References}

Aswad, M., Rahman, F., Said, I. M., Hamuddin, B., \& Nurchalis, N. F. (2019). A Software to Increase English Learning Outcomes: An Acceleration Model of English as the Second Language. The Asian EFL Journal. 26.(6.2), 157-169.

Cameron, D. (2001). Working with Spoken Discourse. Oxford: SAGE Publications, Ltd.

Chaney, A.L., \& Burk, A. L. (1998). Teaching oral Communication in Grades K8.. Boston: Allyn \& Bacon.

Ermawati. (2018). Understanding Teacher's Perceptions toward the Use of ICT Hardware in Creating Learning Environment. Proceeding of the $1^{\text {st }}$ International Conference on English Language Education. Makassar. UIN Alauddin Makassar.

Nunan, D. (1999). Second Language Teaching and Learning. USA: Heinle and Heinle publisher. 
Rahman, F. (2017). Cyber Literature: A Reader Writer Interactivity. International Journal of Social Sciences \& Educational Studies, 3(4), pp. 156-164. https://doi.org/10.23918/ijsses.v3i4p156

Susiati, S., lye, R., \& Suherman, L. (2019). Hot Potatoes Multimedia Applications in Evaluation of Indonesian Learning In SMP Students in Buru District. ELS Journal on Interdisciplinary Studies in Humanities, 2(4), 556-570. https://doi.org/10.34050/els-jish.v2i4.8455

Vander Ark, T. \& Schneider, C. (2012). How Digital Learning Contributes to Deeper Learning. Retrieved from: http://gettingsmart.com/wpcontent/uploads/2012/12/Digital-Learning-Deeper-Learning-Full-WhitePaper.pdf 